\title{
Are global hotspots of endemic richness shaped by plate tectonics?
}

\author{
LOÏC PELLISSIER ${ }^{1,2^{*}}$, CHRISTIAN HEINE ${ }^{3 \dagger}$, DAN F. ROSAUER ${ }^{4}$ and \\ CAMILLE ALBOUY $\mathrm{Y}^{1,2,5}$
}

${ }^{1}$ Landscape Ecology, Institute of Terrestrial Ecosystems, ETH Zürich, Universitätstrasse 16, 8092 Zürich, Switzerland

${ }^{2}$ Swiss Federal Research Institute WSL, Zürcherstrasse 111, 8903 Birmensdorf, Switzerland

${ }^{3}$ EarthByte Group, The University of Sydney, Sydney, NSW 2006, Australia

${ }^{4}$ Research School of Biology and Centre for Biodiversity Analysis, Australian National University, Acton, ACT 2601, Australia

${ }^{5}$ IFREMER, Unité Ecologie et Modèles pour l'Halieutique, rue de l'Ile d'Yeu, BP 21105, 44311 Nantes

Cedex 3, France

${ }^{\dagger}$ Current address: Upstream International New Ventures, Shell International Exploration \& Production

B.V., The Hague, The Netherlands

Received 15 May 2017; revised 12 October 2017; accepted for publication 12 October 2017

\begin{abstract}
The geology of the earth has shown profound changes in the position, connectivity and topography of continents during the last $100 \mathrm{Myr}$, which could have shaped the diversification of lineages and thus the current distribution of biodiversity. Here, we evaluate the association between plate tectonics and the current location of hotspots of endemic richness across the globe. We used palaeogeographies in a model that quantifies, through time and for each geographic cell, the potential dispersal between disconnected habitat areas. We expected that rare dispersal events across barriers of unsuitable habitat allow species colonization, but a subsequent absence of gene flow could lead to in situ speciation. We evaluated whether this process could pinpoint the locations of hotspots of endemic richness computed from the ranges of 181603 species across 14 taxonomic groups. The significant spatial congruence between the model and the endemic richness of several clades provides evidence of the contribution of plate tectonics in shaping global biodiversity gradients. The signal of plate tectonics was independent from those of the Quaternary glaciation, topographical heterogeneity and contemporary productivity and was stronger for terrestrial than freshwater and marine taxa. Regions with high tectonic complexity, predominantly located at the confluence of major lithospheric plates such as the Mediterranean basin, Mesoamerica, Madagascar and South East Asia, probably provided favourable circumstances for allopatric speciation and the emergence of new species across straits. Further efforts should be made to disentangle the effect of past diversification relative to current ecological interactions in shaping global patterns in species diversity.
\end{abstract}

ADDITIONAL KEYWORDS: allopatric speciation - biodiversity - continental drift - dispersal - species richness.

\section{INTRODUCTION}

Biodiversity on Earth is the result of the radiation of lineages in interaction with relentless changes in their environment and is sustained by extant ecological conditions. Convergence of ecological and evolutionary

*Corresponding author. E-mail: loic.pellissier@usys.ethz.ch theories stems from the recognition that the uneven spatial distribution of biodiversity is the product of both contemporary and historical factors (Ricklefs \& Latham, 1993; Mittelbach et al., 2007). The emergence and maintenance of biodiversity have been investigated using a variety of approaches. Based on phylogenies, rates of diversification have been ascribed to regional differences in palaeoenvironmental conditions, highlighting how ancient Earth processes may shape 
extant biodiversity (e.g. Condamine et al., 2012; Near et al., 2012). In particular, plate tectonics have been shown to foster species diversification in geologically active regions (Magri et al., 2007; Li et al., 2013; Bagley \& Johnson, 2014; Richardson et al., 2014). However, macroevolutionary models are based on a very limited number of regions (e.g. low latitude vs. high latitude Pyron, 2014; Pulido-Santacruz \& Weir, 2016), and their power to explain complex spatial gradients is limited. Spatial statistical models provide an alternative approach to explain spatial gradients of biodiversity. Yet, in these models, contemporary factors have more frequently been investigated (e.g. climate or energy; Currie, 1991; Hawkins et al., 2003; Kreft \& Jetz, 2007) than historical proxies (e.g. latitude; Kerkhoff, Moriarty \& Weiser, 2014), and those that have been considered rarely extend beyond the Quaternary (Peter \& Axelrod, 1975; Graham, Moritz \& Williams, 2006; Sandel et al., 2011; Pellissier et al., 2014). Thus, while plate tectonics is recognized to have shaped past and extant biogeographical patterns, in practice, ancient geomorphological dynamics are rarely considered to explain current biodiversity (Descombes et al., 2017). Hence, correlative ecological models may currently underestimate the influence of historical factors on extant biodiversity patterns (Rahbek et al., 2007).

Using spatial statistical models, patterns in the largescale distribution of biodiversity across the globe have been associated with a multitude of variables (Mittelbach et al., 2007). The most commonly proposed driver of biodiversity is energy, in the form of either temperature (Currie, 1991; Hawkins et al., 2003) or primary productivity (Kay et al., 1997; Waide et al., 1999; Jetz et al., 2012), where higher energy should sustain more complex food chains (Briand \& Cohen, 1987). Other extant environmental conditions, including water availability (Qian et al., 2007) or habitat area (Hawkins et al., 2003; Bellwood et al., 2005), show correlations with extant species diversity. Most historical studies investigate whether species distributions are in disequilibrium with extant climate as a legacy of the last glaciations (Graham et al., 2006; Sandel et al., 2011; Pellissier et al., 2014). Yet phylogeographical and palaeontological evidence suggests that geomorphological dynamics reshaped species distributions in the past (Li et al., 2013; Bagley \& Johnson, 2014; Richardson et al., 2014). The legacy of plate tectonics should be detectable today in the diversity of species (Craw et al., 2016). Areas where geomorphological processes have promoted the diversification of lineages in the past should have inherited a comparatively larger number of extant species (Leprieur et al., 2016; Descombes et al., 2017). The association between species richness and topography (Davies et al., 2007), heterogeneity (Stein, Gerstner \& Kreft, 2014) or plate boundaries (Keith et al., 2013) suggests that older processes, for example associated with orogeny, also represented biodiversity pumps (Badgley, 2010). The quest to fully understand the spatial distribution of extant biodiversity must better integrate more ancient processes, which acted concomitantly with the phases of diversification of extant species, usually millions of years old (Hodge \& Bellwood, 2016).

Beyond the overarching gradient of biodiversity with latitude, particular regions of the globe form hotspots, hosting a disproportionally large fraction of extant biodiversity. For instance, at comparable latitudes and climates, Asia is considerably more diverse than the Americas or Africa for plants (Ricklefs, 2004; Couvreur, 2015). Similarly, the biodiversity of the Neotropics is thought to have largely emerged from geological activities, for example associated with orogeny (Hoorn et al., 2010). Within the last $\sim 100 \mathrm{Myr}$, diversification gave rise to most modern lineages, including within birds (Barker et al., 2004), mammals (Meredith et al., 2011) and higher plants (Magallón \& Castillo, 2009). During this period of diversification, plate tectonics dramatically remodelled the structure of terrestrial landscapes and nearshore marine habitats and should have left a legacy on current diversity (Renema et al., 2008; Leprieur et al., 2016). Evidence suggests that the emergence of biodiversity is linked to geology for both marine and terrestrial organisms (Briggs, 1987; Morley, 1998). Among the geological processes shaping biodiversity, the convergence of tectonic plates promotes environmental heterogeneity through building of topography. Temporal changes in convergence kinematics along subduction zones (such as the Andes) can generate significant vertical crustal motions. Towards the end of a Wilson cycle, collision of continental plates generates Alpine-Himalayan type mountain chains, which enhance the diversification of organisms, for example plant (Hoorn et al., 2010) and animal lineages (Toussaint et al., 2014). Other geological processes, such as the emergence of islands associated with volcanism, are also expected to contribute to species diversification through allopatric speciation (Briggs, 2003; Bidegaray-Batista \& Arnedo, 2011). By isolating populations with oceanic gateways, fuelled by sporadic events of dispersal across straits (Lavergne, Hampe \& Arroyo, 2013), plate divergence may represent a further major catalyst of speciation (Steeman et al., 2009). Nevertheless, the processes of plate tectonics are rarely considered when modelling the current spatial distribution of biodiversity.

Biodiversity has many facets, and the signal of history may be stronger in some than others (Sandel et al., 2011). For instance, species with large range size are generally associated with high dispersal abilities (Bowman, Jaeger \& Fahrig, 2002; Lester et al., 2007). Hence, the extant distribution of these species can 
extend far from their origin, eroding the signal of the historical process that led to their diversification. In contrast, endemic species - at least those not resulting from range contractions - are more frequently found in their specific locations of origin (e.g. Vetaas \& Grytnes, 2002; Barluenga et al., 2006). The level of endemism may thus show a stronger association with regional geological processes. Biogeographical analyses have already shown a congruence between panbiogeographical nodes of geological origin and areas of endemism (Contreras-Medina, Morrone \& Lunz Vega, 2001; Luna-Vega \& Contreras-Medina, 2010). For instance, high endemic richness in Madagascar is associated with a long history of geological separation of the island (Ali \& Huber, 2010). However, novel mechanistic modelling approaches are required to test for a more general link between plate tectonics and endemism at a global scale.

Here, we evaluate the congruence between the dynamics of plate tectonics and current hotspots of species endemism. We used a spatial model that quantifies dynamically the role of plate movements in providing opportunities to generate biodiversity at the margins of continental plates. Allopatry is thought to be the dominant force of speciation (Futuyma \& Mayer, 1980; Gastauer et al., 2015), and this mechanism may generate a higher diversity of species endemic to regions subject to plate divergence (Raven \& Axelrod, 1974; Molina-Venegas et al., 2015). Since it is less subject to diffusion after diversification, endemic richness should provide a stronger signal than species richness (Descombes et al., 2017). We identified locations, where high diversity is expected from a speciation process linked to plate movements, and compared these locations to the distribution of 'hotspots', the cells with the highest endemic richness worldwide in a data set of 181603 species across 14 taxonomic groups in marine, freshwater and terrestrial environments. We had the following expectations:

1. Regions of highest endemic richness should be congruent with regions of plate divergence or convergence, which fostered dispersal and ultimately speciation among patches separated by unsuitable habitat.

2. The relationship between plate tectonics and endemic richness should be independent of other historical factors associated with the glaciations of the Quaternary and independent of contemporary factors, including topographical heterogeneity and productivity.

Together, we expect that the availability of palaeohabitat reconstructions mapping of the potential speciation generated by plate movement should provide the missing link between past tectonic activity and its consequences on the current global distribution of endemic richness.

\section{MATERIAL AND METHODS}

\section{SPECIES DATA AND ENDEMIC RICHNESS}

We mapped endemic richness globally using an indicator that combines information on species endemism and species richness (Kier et al., 2009), by calculating the sum of the inverse range sizes of all species occurring in each grid cell. This metric was calculated from gridded species distributions for 181603 species in terrestrial, freshwater and marine ecosystems, consisting of (1) 154507 terrestrial species (6309 amphibians, 5289 mammals, 128565 plants, 4278 reptiles, 10066 birds); (2) 9597 freshwater species (1277 crabs, 1887 molluscs, 135 plants, 6298 fishes); and (3) 17499 marine species (844 corals, 632 cone snails, 369 sea cucumbers, 61 sea snakes, 15593 fishes). Each species range size was measured as the number of grid cells in which a species occurs across the globe using an equal-area projection.

For most species (amphibians, mammals, reptiles, corals, cone snails, sea cucumbers, crabs, molluscs, freshwater plants and freshwater fishes), distribution data were obtained from the IUCN web site (accession date: 30 November 2016). Bird distribution maps were obtained from BirdLife International (BirdLife International \& NatureServe, 2015). For the scale and resolution of the current study, IUCN and BirdLife polygons represent the distribution of species with sufficient accuracy, and such data have been used in many analyses in macroecology (e.g. Hurlbert \& Jetz, 2007; Marin \& Hedges, 2016). For the plants, we used regional species checklists of all families present in the Kew Checklist database from the Taxonomic Databases Working Group (TDWG). We used checklists corresponding to the most detailed 'Level 3' TDWG polygons (http://www.tdwg.org/, http://www. kew.org/science-conservation/research-data/resources/ gis-unit/tdwg-world). Polygons generally correspond to countries, although larger countries are often subdivided into states, or islands, for example in South East Asia.

Fish species data were obtained from the Ocean Biogeographic Information System (OBIS; http://www.iobis.org). We inventoried 16238200 occurrence records. We cleaned the data by identifying synonyms, misspellings and rare species (only one occurrence). Synonyms were replaced with accepted names. This resulted in a set of 11503257 occurrences for 11345 fish species around the world. We reconstructed distribution maps for each species, defined 
as the convex polygon surrounding the area where each species was observed. The resulting polygon was divided into four parts across the world to integrate possible discontinuity between the two hemispheres and the Atlantic and Pacific Oceans. For instance, antitropical species are distributed in the northern and southern hemisphere, but show a range discontinuity near the tropics (Briggs, 1987), and a polygon division allows this to be accounted for. We refined each species distribution map by removing areas where depths did not include the known depth range of the species from FishBase. As the OBIS database did not represent well the tropical assemblage of fish, we merged it with the Gaspar database that encompasses 6316 coral reef species (Pellissier et al., 2014). We obtained a world database containing 15593 fish species. We transformed individual species shapefiles into equal-area raster grids. All maps of endemic richness were then projected into global longitude-latitude projection $1^{\circ}$-resolution grids to match environmental variables.

As a complement to endemic richness, phylogenetic endemism can pinpoint areas where substantial components of phylogenetic diversity are restricted (Rosauer et al., 2009). Phylogenetic endemism can show associations with both contemporary and historical variables such as Wallace's Line (Rosauer \& Jetz, 2015). The geographic range is calculated for each branch in the tree, including the union of the ranges of all descendant taxa in a clade, such that overlapping areas were counted only once. Data are available for mammals, allowing a comparison of the metric of endemic richness and phylogenetic endemism (Rosauer \& Jetz, 2015). We evaluated the correlation between endemic richness and phylogenetic endemism for the analysed clade to evaluate the congruence of the two metrics.

\section{Plate TECTONIC RECONSTRUCTION}

Reconstructions of palaeoenvironments are needed to understand which regions were historically the most likely to promote the emergence of biodiversity (Svenning et al., 2015). Here, we used palaeoreconstructions of the position of continents, coastlines and palaeobathymetry (Müller et al., 2008; Heine, Yeo \& Müller, 2015) from the Early Cretaceous (140 Mya) to the present in $1 \mathrm{Myr}$ steps as boundary conditions for our models. We used the GPlates open source software (http://www.gplates.org) in conjunction with a set of digital palaeoshoreline positions (Heine et al., 2015) and a model of global plate motion to generate gridded, individual palaeogeographic reconstructions for land surface area at any given time step. While there are uncertainties, the palaeogeography of Heine et al. (2015) is a detailed open access global data set providing reconstructions at regular time steps of $1 \mathrm{Myr}$. We focused on the period spanning the last $140 \mathrm{Myr}$, which was characterized by significant changes in the position of the tectonic plates across the globe, for example from the breaking of the Gondwana supercontinent, followed by the rapid northward motion of India and Australia. This period also represents the time window during which many extant clades diversified (Meredith et al., 2011; Jetz et al., 2012) possibly under the influence of plate tectonics. Nonetheless, because the peak of diversification of some of the groups occurred more recently, for example in the Miocene (Santos et al., 2009), we ran a sensitivity analysis that considered different starting dates for the simulations $(100,80$, 60 and $40 \mathrm{Mya})$.

\section{MODELLING THE POTENTIAL FOR SPECIATION}

We developed a model based on habitat dynamics, which quantifies the amount of potential dispersal into each cell from disconnected patches separated by unsuitable areas (i.e. of sea for terrestrial species or deep sea and land for marine species; Fig. 1; Supporting Information, Figs S1, S2). Rare dispersal across geographic barriers should allow the establishment of new populations, but gene flow is subsequently almost non-existent, leading to in situ speciation. Classical examples of colonization of remote areas such as islands (e.g. Guzmán \& Vargas, 2009; Gillespie \& Roderick, 2014) followed by local speciation support the possibility of dispersal across straits on geological time scales (Cowie \& Holland, 2006). Our model records for each point in time and for each cell, the number of cells from disconnected patches from which it can receive dispersers, which would potentially give rise to a new species. During each million-year time slice, the simulation first defines the patches separated by at least one cell of unsuitable area using an algorithm of cluster splits implemented in the 'dbscan' function in the fpc library in R. The model then quantifies for each cell, the number of surrounding cells from disconnected patches within a dispersal distance $d$. A higher number of possible donor cells are assumed to increase the chance of dispersal across a barrier. To accommodate the movement of the continents, the cell values at time $t$ added to the value of potential incoming dispersal are transferred to the closest cell at time $t+1$. Areas with the greatest potential incoming dispersal across barriers for an extended duration are expected to have the highest potential for allopatric speciation, shaping species richness and endemism across barriers. We tested a range of values of dispersal $d\left[5,10,15,20,25,30\left(^{\circ}\right)\right]$ for both terrestrial and marine ecosystems (Supporting Information, Figs S4, S6).

The previous proxy only covers a mechanism for the generation of new species, but fails to account for extinction. Extinction is thought to be associated with the more intense climatic fluctuation towards the poles 

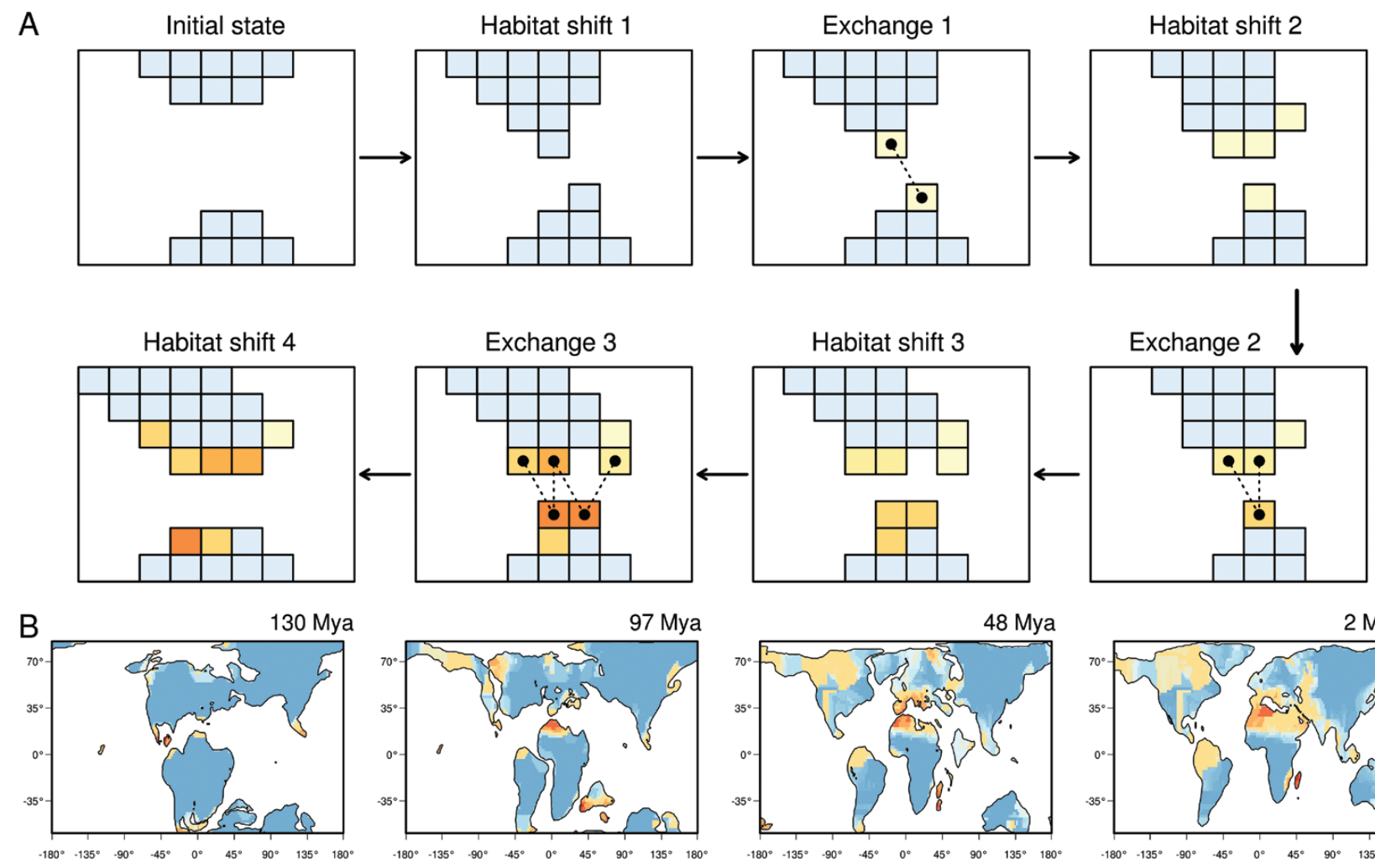

\section{Exchange 3}
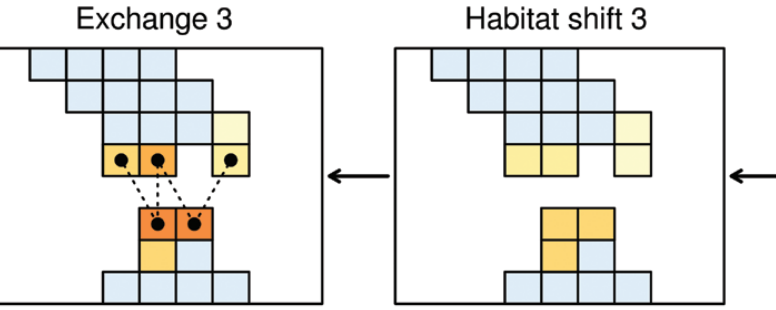

Exchange 2
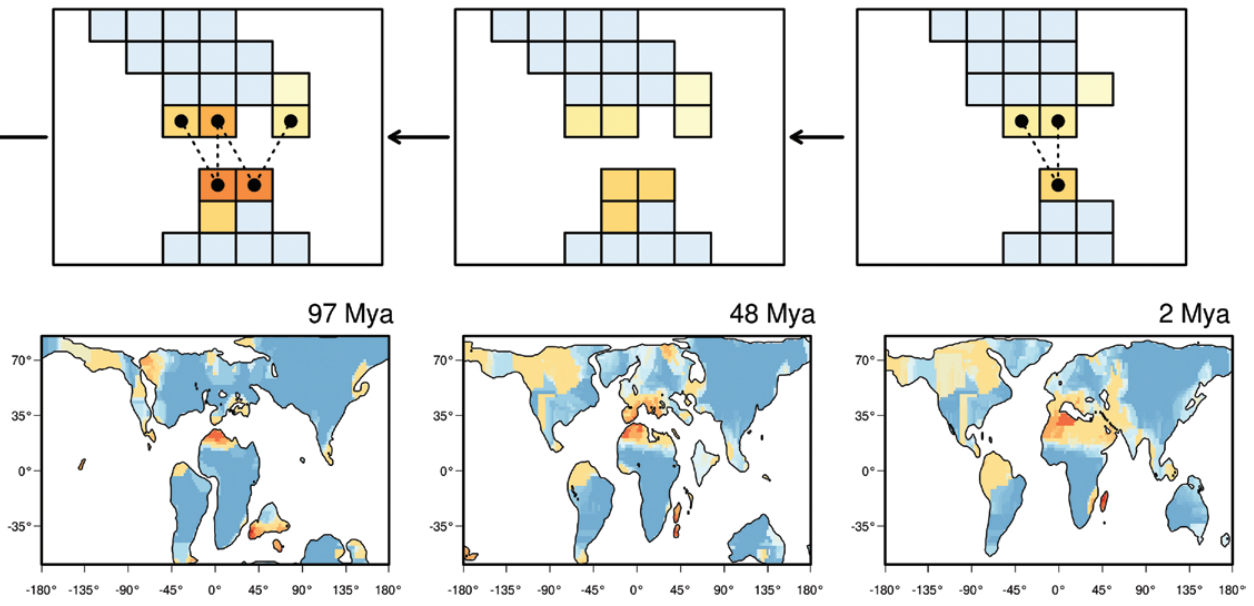

Figure 1. A, illustration of the mechanism used to produce the spatial proxy of speciation potential due to plate tectonics, including from left to right, alternating phases of (1) habitat change and (2) exchange among cells. During each million-year time slice, the simulation first defines the patches separated by at least one cell of unsuitable habitat. The model identifies for each cell, the number of surrounding 'donor' cells from disconnected habitat patches below a dispersal distance $d$ (linked by dashed lines). A higher number of possible donor cells are assumed to increase the chance of long-distance dispersal across a barrier (intensity of shading). To accommodate the movement of the continents, the cell values at time $t$ are transferred to the closest new cells at time $t+1$. B, examples of four palaeogeographies showing the terrestrial locations with high potential for speciation across straits for 130, 97, 48 and 2 Mya.

(Dynesius, Jansson \& Fischer, 2000). To account for a gradient in extinction rate associated with latitude and better highlight the locations of biodiversity hotspots, we created filters assuming that survival decreases linearly (or with a Gaussian shape see Supporting Information, Figs S5, S7 for results) either with latitude with an $X$-intercept at 0 and a $Y$-intercept corresponding to the maximum number in the potential for allopatric speciation. We computed the difference between the maps of the potential for allopatric speciation and the potential filtering effect of extinction to further refine the locations of biodiversity hotspots.

\section{ADDITIONAL ENVIRONMENTAL VARIABLES}

To evaluate whether plate tectonics provide independent information compared to other influential environmental factors, we assembled maps of extant productivity, topographical heterogeneity and climate change velocity during the glaciations of the Quaternary. For the terrestrial environment, we considered annual net primary productivity ( $\mathrm{g} \mathrm{C} / \mathrm{m}^{2} /$ year) as computed by Imhoff \& Bounoua (2006), elevation heterogeneity computed as in Descombes et al. (2017) and climate change velocity during the Quaternary (Sandel et al., 2011). Climate velocity is an indicator of the distance that species had to move each year to track suitable conditions during the Quaternary climate fluctuations. For the marine environment, we considered primary productivity (http://gmed.auckland.ac.nz/data.html), bathymetric heterogeneity computed as in Descombes et al. (2017) and Quaternary climate change velocity. Velocity of climate change during the glaciations was computed from reconstructed temperature at the last glacial maximum (LGM) from the MARSPEC layers (Sbrocco \& Barber, 2013). We computed past climate change velocity by comparing current and past sea surface temperature at the LGM, calculated as the distance between a cell and the closest cell with the same temperature (rounded in ${ }^{\circ} \mathrm{C}$ ) during the LGM. 


\section{SPATIAL CONGRUENCE ANALYSIS}

We tested whether there is a significant spatial congruence between the regions of endemism predicted by the model and the observed endemic richness. For each comparison between observed and predicted maps, we evaluated the spatial match between the cells with the highest endemic richness and those with the highest expected value predicted by the model. To assess whether the observed number of overlapping cells is significantly different from that obtained by chance, we used a randomization procedure as in Mouillot et al. (2011). We randomly redistributed the value of expected diversity 999 times within the grid and counted the number of overlapping cells for each. We computed the $P$-values by counting the number of times for which the match of the randomized data with the observed endemic richness was as good as or better than that of the prediction from the model. We tested the sensitivity of this analysis to the selection of the threshold by successively using $2.5,5,7.5,10,12.5$ and $15 \%$ thresholds to classify what was regarded as the highest values of richness.

\section{SPATIAL AUTOREGRESSIVE MODEL}

We related endemic richness to the variable derived from plate tectonics together with Quaternary climate change velocity, topographical heterogeneity and contemporary productivity, using a spatial autoregressive (SAR) model (Kissling \& Carl, 2008). To provide conservative results and since the effect of glaciation is accounted for by the variable of climatic velocity, we used the variable from plate tectonics without the extinction filter. For each taxonomic group, we used the variable of speciation potential due to plate tectonics with the dispersal distance parameter that yielded the highest spatial congruence with levels of endemism in the analysis described above. The SAR model incorporates a spatially dependent error term to adjust for spatial autocorrelation. We used a spatial weight matrix with neighbourhoods defined as all cells within $200 \mathrm{~km}$ of the focal cell. Variables were standardized to allow direct comparison of their respective slopes in the SAR models.

\section{RESULTS}

\section{CONGRUENCE ANALYSIS}

Our model simulating a mechanism of speciation associated with plate tectonics pinpoints several regions with high potential for speciation, namely Meso-America, the circum-Mediterranean basin, Madagascar and the Sundaland region of South East Asia (Fig. 2). Two additional regions at higher latitude in the archipelago of Northern Canada and between Patagonia and Antarctica are also apparent, but their general influence is attenuated once the extinction is considered (Supporting Information, Figs S11, S12). Terrestrial regions that have undergone significant tectonic deformation potentially generating species across straits showed a significant match with the hotspots of endemic richness, with $29 \%$ of common grid cells ( $47 \%$ when accounting for extinction) for land organisms and $27 \%$ ( $25 \%$ with the extinction filter) for terrestrial freshwater organisms (Table 1). Among the multiple clades investigated, the congruence was the highest for freshwater vascular plants with $40 \%$ (46\% with the extinction filter, Supporting Information, Tables S1, S2) mainly due to their more pronounced match in the Mediterranean area. Applied to the marine realm, the model showed broader areas with high expected diversity, including the Indo-Australian archipelago, the region of Madagascar, the circum-Mediterranean Sea and the Southern Atlantic. In contrast to terrestrial clades, the congruence of the expectations of the model and the regions of high endemic richness was low, with only $12 \%$ of matching cells ( $25 \%$ with extinction). The highest level of congruence was found for sea cucumbers with $18 \%$ of overlap (33\% with extinction). Results with different thresholds were very similar, so we only present those using a 10\% threshold for the definition of hotspots in the main manuscript (see Supporting Information, Table S3 for results using other values). We found a strong correlation between endemic richness and phylogenetic endemism for mammals (Pearson's correlation $=0.88$; Supporting Information, Fig. S10), suggesting that species endemism is spatially associated with the endemism of lineages. The sensitivity analysis using different starting dates to generate the predictor of the effect of geomorphological dynamics provided similar distributions of expected diversity as the full simulation starting at 140 Mya (Supporting Information, Fig. S1).

\section{SPATIAL AUTOREGRESSIVE MODEL}

The relationship between endemic richness and geodynamics received strong support in the SAR models considering historical and contemporary variables for terrestrial (SAR model: slope $=0.105, P<0.001$; Table 2), marginal support for freshwater (SAR model: slope $=0.073, P<0.1)$ and no support for marine (SAR model: slope $=-0.001, P>0.1$ ) taxonomic groups. All the terrestrial taxonomic groups with the exception of birds showed a significant relationship with the proxy of plate tectonics, while only molluscs among freshwater groups and cone snails among marine groups showed a significant relationship once the other environmental factors were accounted for in the SAR 

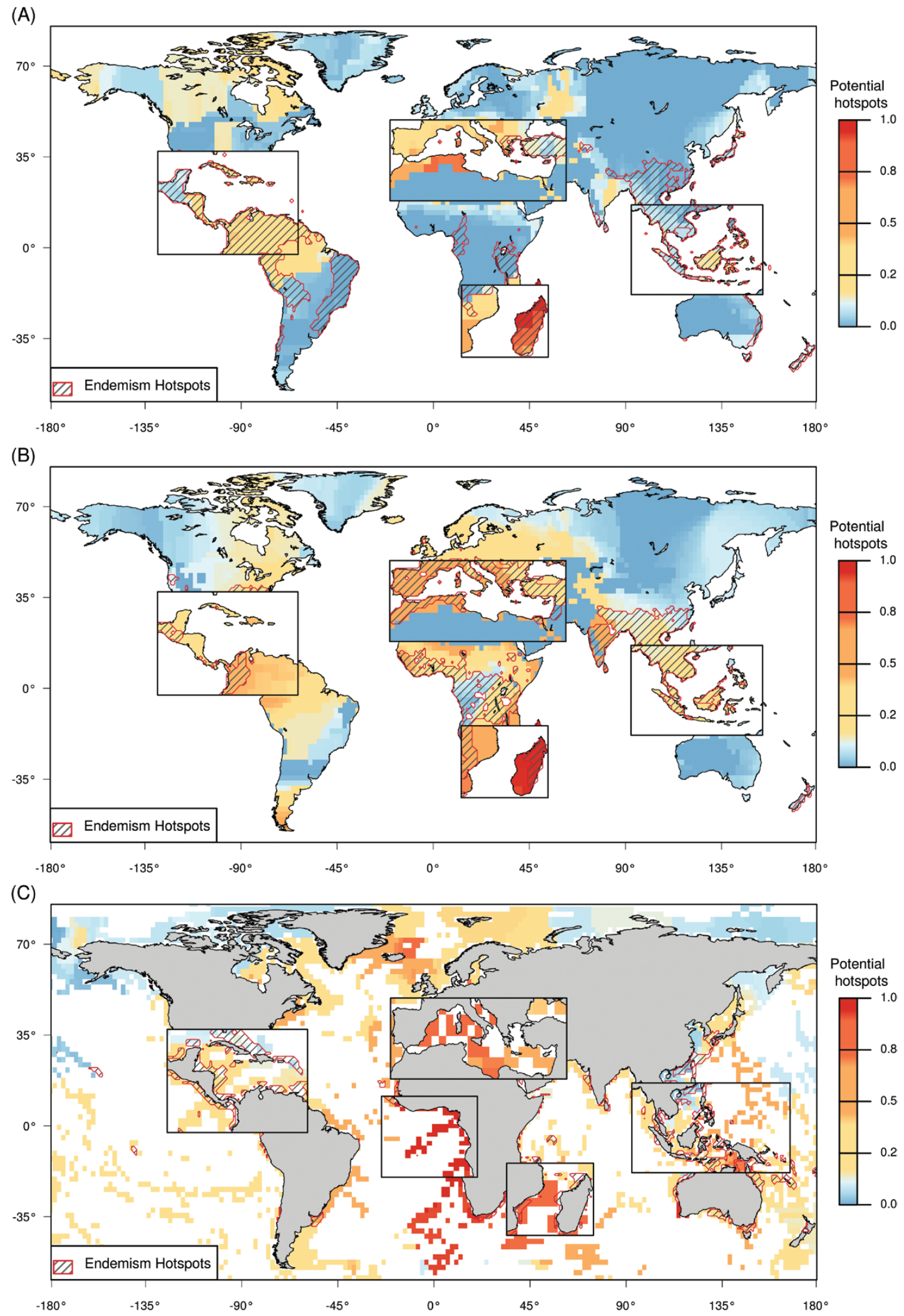

Figure 2. Map of the proxy of the potential for speciation associated with plate tectonics for the (A) terrestrial, (B) freshwater and $(\mathrm{C})$ marine species ( $d=10$ for $\mathrm{A}$ and $\mathrm{C} ; d=25$ for $\mathrm{B}$ ). The most important areas that provided favourable circumstances 
Table 1. Statistical tests of congruence between simulated and observed endemic richness hotspots for terrestrial, freshwater and marine species

\begin{tabular}{|c|c|c|c|c|c|}
\hline & $d$ & Number of common cells & Expected overlap & $P$-value & $\begin{array}{l}\text { Percent of common } \\
\text { hotspots }\end{array}$ \\
\hline Total terrestrial & 10 & 435 & 154.47 & 0.001 & 28.79 \\
\hline Amphibians & 30 & 395 & 151.27 & 0.001 & 26.14 \\
\hline Mammals & 30 & 349 & 151.27 & 0.001 & 23.10 \\
\hline Reptiles & 20 & 385 & 151.27 & 0.001 & 25.48 \\
\hline Plants & 30 & 438 & 152.37 & 0.001 & 28.99 \\
\hline Birds & 10 & 449 & 154.47 & 0.001 & 29.72 \\
\hline Total freshwater & 25 & 407 & 151.27 & 0.001 & 26.94 \\
\hline Crabs & 30 & 440 & 151.57 & 0.001 & 29.12 \\
\hline Molluscs & 20 & 571 & 151.27 & 0.001 & 37.79 \\
\hline Plants & 25 & 606 & 151.27 & 0.001 & 40.11 \\
\hline Fishes & 25 & 335 & 151.27 & 0.001 & 22.17 \\
\hline Total marine & 10 & 117 & 101.26 & 0.042 & 11.65 \\
\hline Corals & 15 & 132 & 100.56 & 0.001 & 13.15 \\
\hline Cone snails & 15 & 128 & 100.86 & 0.002 & 12.75 \\
\hline Sea snakes & 10 & 55 & 101.46 & 1 & 5.48 \\
\hline Sea cucumbers & 25 & 181 & 100.66 & 0.001 & 18.03 \\
\hline Fishes & 10 & 123 & 101.26 & 0.011 & 12.25 \\
\hline
\end{tabular}

The endemic richness was calculated as the sum of the inverse range sizes of all species occurring in a given grid cell. Results are shown for the value of dispersal distance $(d)$ in the simulation that resulted in the greatest congruence with observed endemism. The number of common cells indicates the number of overlapping cells among the $10 \%$ of the highest values of endemic richness and in the simulation. The expected overlap corresponds to the mean number of overlapping cells expected from the randomization of the simulated data 999 times.

models. In contrast, heterogeneity and primary productivity were associated with endemic richness for terrestrial, freshwater and marine taxonomic groups overall and for many individual groups (Table 2).

\section{DISCUSSION}

The current climate constrains the number of species that can survive at a given place, for instance through processes of environmental filtering along latitude (Sommer et al., 2014). It is, however, not sufficient to explain the full regional variability of species diversity across the globe (Ricklefs, 2004; Ricklefs \& He, 2016). In addition to ecological factors such as productivity (Waide et al., 1999; Jetz et al., 2012), biodiversity gradients can be related to historical events of speciation and extinction, the intensity of which varied across regions (Pellissier et al., 2014; Svenning et al., 2015). Interestingly, many regions recognized for their high diversity or degree of endemism, such as Mesoamerica, Madagascar or South East Asia, are situated in proximity to continental plate margins, where previously joined continental crust was either rifted apart or is converging, providing clues to the role of plate tectonics in shaping biodiversity hotspots. Here, we provide evidence of congruence between a spatial proxy for the effect of plate tectonics on species diversification and global patterns of endemic richness for terrestrial clades. Our results suggest that, in agreement with many phylogeographical or palaeontological analyses, deep time historical factors should be considered to explain the current distribution of biodiversity.

\section{CONGRUENCE BETWEEN PLATE TECTONICS AND ENDEMIC RICHNESS}

The model, which quantifies the amount of potential dispersal into each cell from disconnected patches under plate tectonics, was congruent with the observed distribution of endemic richness of several clades and showed significant correlations independent of other relevant variables. The dynamics of continental separation and the formation of narrow, deep water oceanic basins

for speciation are highlighted by the enlarged insets. These correspond, for the terrestrial taxa, to the Mediterranean basin, Central America, Madagascar and South East Asia. The distributions of cells with the highest $10 \%$ of values of endemic richness are represented by hatched regions. 
Table 2. Results of the statistical analyses of spatial autoregressive models for total terrestrial, marine and freshwater organisms and for each taxonomic group separately

\begin{tabular}{|c|c|c|c|c|c|c|c|c|}
\hline \multicolumn{3}{|l|}{ Terrestrial } & \multicolumn{3}{|l|}{ Marine } & \multicolumn{3}{|l|}{ Freshwater } \\
\hline Group & Variable & Estimate & Group & Variable & Estimate & Group & Variable & Estimate \\
\hline Total terrestrial & NPP & $0.334 * * *$ & $\begin{array}{l}\text { Total } \\
\text { marine }\end{array}$ & NPP & $0.224 * * *$ & $\begin{array}{l}\text { Total } \\
\quad \text { freshwater }\end{array}$ & NPP & $0.060 * * *$ \\
\hline$d=10$ & $\begin{array}{l}\text { Heter } \\
\text { Velocity } \\
\text { LBE }\end{array}$ & $\begin{array}{r}0.074 * * * \\
-0.077^{* * *} \\
0.105^{* * *}\end{array}$ & $d=10$ & $\begin{array}{l}\text { Heter } \\
\text { Velocity } \\
\text { LBE }\end{array}$ & $\begin{array}{c}0.042^{* * *} \\
0.006 \\
-0.001\end{array}$ & $d=25$ & $\begin{array}{l}\text { Heter } \\
\text { Velocity } \\
\text { LBE }\end{array}$ & $\begin{array}{l}0.028^{* * * *} \\
-0.020 \\
0.073(*)\end{array}$ \\
\hline $\begin{array}{l}\text { Amphibians } \\
d=30\end{array}$ & $\begin{array}{l}\text { NPP } \\
\text { Heter } \\
\text { Velocity } \\
\text { LBE }\end{array}$ & $\begin{array}{l}0.166^{* * *} \\
0.166^{* * *} \\
-0.04^{*} \\
0.10^{* * *}\end{array}$ & $\begin{array}{l}\text { Corals } \\
d=15\end{array}$ & $\begin{array}{l}\text { NPP } \\
\text { Heter } \\
\text { Velocity } \\
\text { LBE }\end{array}$ & $\begin{array}{l}0.0184(*) \\
0.003 \\
-0.035^{* *} \\
0.020\end{array}$ & $\begin{array}{l}\text { Crabs } \\
d=30\end{array}$ & $\begin{array}{l}\text { NPP } \\
\text { Heter } \\
\text { Velocity } \\
\text { LBE }\end{array}$ & $\begin{array}{l}0.067 \text { *** } \\
0.039^{* * *} \\
-0.021 \\
0.037\end{array}$ \\
\hline $\begin{array}{l}\text { Mammals } \\
d=30\end{array}$ & $\begin{array}{l}\text { NPP } \\
\text { Heter } \\
\text { Velocity } \\
\text { LBE }\end{array}$ & $\begin{array}{c}0.25^{* * *} \\
0.124^{* * *} \\
-0.07^{* * *} \\
0.118^{* * *}\end{array}$ & $\begin{array}{l}\text { Cone snails } \\
d=15\end{array}$ & $\begin{array}{l}\text { NPP } \\
\text { Heter } \\
\text { Velocity } \\
\text { LBE }\end{array}$ & $\begin{array}{l}0.052^{* * * *} \\
0.051^{* * *} \\
0.024 \\
0.036^{*}\end{array}$ & $\begin{array}{l}\text { Molluscs } \\
d=20\end{array}$ & $\begin{array}{l}\text { NPP } \\
\text { Heter } \\
\text { Velocity } \\
\text { LBE }\end{array}$ & $\begin{array}{l}0.060^{* * * *} \\
0.012 \\
-0.039^{*} \\
0.081^{* * *}\end{array}$ \\
\hline $\begin{array}{l}\text { Reptiles } \\
d=20\end{array}$ & $\begin{array}{l}\text { NPP } \\
\text { Heter } \\
\text { Velocity } \\
\text { LBE }\end{array}$ & $\begin{array}{c}0.137^{* * *} \\
0.114^{* * *} \\
-0.045^{* *} \\
0.212^{* * *}\end{array}$ & $\begin{array}{l}\text { Sea snakes } \\
d=10\end{array}$ & $\begin{array}{l}\text { NPP } \\
\text { Heter } \\
\text { Velocity } \\
\text { LBE }\end{array}$ & $\begin{array}{l}0.102^{* * * *} \\
-0.008 \\
-0.116^{* * * *} \\
-0.0001\end{array}$ & $\begin{array}{l}\text { Plants } \\
d=25\end{array}$ & $\begin{array}{l}\text { NPP } \\
\text { Heter } \\
\text { Velocity } \\
\text { LBE }\end{array}$ & $\begin{array}{l}0.021^{* *} \\
0.008^{*} \\
0.004 \\
0.05\end{array}$ \\
\hline Plants & NPP & $0.306^{* * *}$ & $\begin{array}{l}\text { Sea } \\
\quad \text { cucumbers }\end{array}$ & NPP & $0.050 * * *$ & Fishes & NPP & 0.011 \\
\hline$d=30$ & $\begin{array}{l}\text { Heter } \\
\text { Velocity } \\
\text { LBE }\end{array}$ & $\begin{array}{r}0.059 * * * \\
-0.070^{* * *} \\
0.086 * * *\end{array}$ & $d=25$ & $\begin{array}{l}\text { Heter } \\
\text { Velocity } \\
\text { LBE }\end{array}$ & $\begin{array}{l}0.010(*) \\
0.020 \\
0.037\end{array}$ & $d=25$ & $\begin{array}{l}\text { Heter } \\
\text { Velocity } \\
\text { LBE }\end{array}$ & $\begin{array}{c}0.03^{* * *} \\
-0.009 \\
0.001\end{array}$ \\
\hline $\begin{array}{l}\text { Birds } \\
d=10\end{array}$ & $\begin{array}{l}\text { NPP } \\
\text { Heter } \\
\text { Velocity } \\
\text { LBE }\end{array}$ & $\begin{array}{c}0.146 * * * \\
0.108^{* * *} \\
-0.027^{*} \\
0.018\end{array}$ & $\begin{array}{l}\text { Fishes } \\
d=10\end{array}$ & $\begin{array}{l}\text { NPP } \\
\text { Heter } \\
\text { Velocity } \\
\text { LBE }\end{array}$ & $\begin{array}{l}0.0115 \\
0.030^{* * * *} \\
-0.009 \\
0.001\end{array}$ & & & \\
\hline
\end{tabular}

The slopes of the relationship between endemic richness and each variable are shown. Values for $d$ are those?? Values for $d$ are those selected according to the statistical tests of congruence between simulated and observed endemic richness hotspots (see Table 1). NPP, net primary productivity; Heter, topographical heterogeneity; velocity, climate change velocity.

(*) $P<0.1, * P<0.05, * * P<0.01, * * * P<0.001$

probably permitted rare events of dispersal followed by allopatric speciation (Xiang \& Soltis, 2001; Lavergne et al., 2013) and corroborates the idea that plate tectonic processes over time and space shaped regions of exceptional endemic richness (Gillespie \& Roderick, 2014; Couvreur, 2015). For instance, phylogeographical inferences suggest that dispersal from eastern Asia to insular areas in South East Asia coincides with the timing of major tectonic activity and the collision between the Sunda and Sahul shelves, which caused continental fragments to be rearranged throughout the region (Bacon et al., 2013). When populations are established after dispersal across oceanic gateways, isolation prompts the emergence of disparate gene pools, which ultimately leads to speciation (Ali \& Aitchison, 2014). The model highlighted some of the regions of the globe with the highest levels of endemic richness, including the Mediterranean basin, Mesoamerica, Madagascar and South East Asia (Fig. 2). In agreement with our model, evidence suggests that periodic dispersal events between land masses triggered species diversification, with known examples being those between the North, Central and South American plates (Bagley \& Johnson, 2014), across the Iberian, Adriatic and African tectonic plates in the Mediterranean basin (Lavergne et al., 2013) or in the Indo-Australian archipelago (Warren et $a l .$, 2010). Similarly, the early separation of Madagascar followed by asymmetrical exchanges with the coast of 
Africa probably enhanced speciation and promoted a high level of endemism on the island (Ali \& Huber, 2010). Moreover, a palaeostrait at Cape Horn putatively shaped high diversity in the South America-Antarctic Peninsula region, which has revealed an exceptional fossil plant diversity in the Eocene (Wilf et al., 2005).

Overall, the model showed a good match with observations for the land, but a lower match for the marine realm (Table 1). We hypothesize that deep water oceanic gateways between shallow shelf areas are probably much more permeable for marine organisms than are shallow epicontinental sea straits for terrestrial taxa (Palumbi, 1994). The separation of shallower reefs by areas of deep water is not necessarily associated with speciation since larvae of marine species can disperse over large distances (Luiz et al., 2013), which would explain the discrepancy between the model and observations (Fig. 1). As further evidence of variation in speciation mechanisms among ecosystems, the model pinpointed different values of $d$ for the marine compared to the terrestrial ecosystem and only showed significant effects in the SAR models for terrestrial taxa. Our results support the idea that the marine realm is more permeable to the movement of organisms (Palumbi, 1994). We also found differences among the terrestrial taxa in both the dispersal values and the slope of the relationship with geomorphological dynamics in the SAR model. For instance, birds, which have higher dispersal abilities than other vertebrate groups, showed values of endemic richness that were not related to plate tectonics when other variables were considered, paralleling differential taxonomic responses to the glaciations of the Quaternary (Sandel et al., 2011).

Because phylogenies were not available for most of the taxonomic groups considered, we investigated endemic richness instead of phylogenetic endemism (Rosauer et al., 2009). However, the extant species analysed are younger that many of the geological events considered in the plate tectonic model. Nevertheless, as lineages accumulate in specific regions, so does species number, generating a spatial congruence between endemic richness and phylogenetic endemism (Supporting Information, Fig. S6). While we only compared endemic richness to phylogenetic endemism in mammals, we expect that the congruence between these metrics is general. Hence, the dynamics of plate tectonics that occurred more than a few million years ago may have catalysed allopatric speciation of the hypothetical ancestors of the species that we can recognize nowadays, but this too increased the eventual number of species in the region. Future comparisons of spatial diversification models with empirical data should directly compare genealogies inferred from models to the structure of phylogenies of clades (Descombes et al., 2017).

\section{UNEXPLAINED VARIATION AND LIMITATIONS OF THE STUDY}

Most of the species for which the distribution was modelled have evolved relatively recently and other factors (e.g. Quaternary climate, availability of habitats and habitat types) have contributed to their current distributional patterns. The congruence between the geodynamics and endemic richness ranged from 20 up to $46 \%$, indicating considerable unexplained variation. The SAR models showed a significant effect of productivity and heterogeneity in most of the investigated taxonomic groups, while the effect of the velocity of Quaternary climate change was especially pronounced for terrestrial taxa. Hence, despite an association with geodynamics, other historical and contemporary factors are likely to have shaped the distribution of endemism (Sandel et al., 2011). The SAR models also indicated a consistent relationship between topographical heterogeneity and endemic richness. One of the main drawbacks of the current approach is that it does not integrate orogeny, thus failing to consider how mountain-building contributes to speciation. Improving the details of tectonic and palaeoelevation reconstructions will allow a better quantification of how plate tectonics shaped the extant spatial gradients of biodiversity. Our model has further limitations linked to the coarseness of the continental reconstructions used in our analyses. For example, the potential for allopatric speciation is likely to be underestimated in South East Asia because the patchiness of small islands is not well represented in our global model. In addition, the continental plate reconstruction only includes the formation of large islands caused by massive hot spot volcanism (e.g. Kerguelen, Ontong-Java) but not smaller volcanic islands or island arc chains due to subduction processes, which are also expected to have promoted exceptional biodiversity hotspots. Finally, islands also provide stepping stones that allow colonization or gene flow among areas (Harbaugh et al., 2009) and influence the regional potential for speciation. Islands are extremely difficult to model and future palaeogeographic reconstructions should integrate them with greater accuracy. Improvement in the reconstruction of past habitats should provide better constraints for dynamic biodiversity models.

\section{TOWARDS BETTER PALAEOENVIRONMENTAL RECONSTRUCTIONS}

In recent years, significant progress has been made in reconstructing the bathymetric evolution of ocean basins over the past $230 \mathrm{Myr}$ (Müller et al., 2008, 2016), along with advances in assimilating global data sets on the distribution of palaeoshorelines (Heine et al., 2015). These palaeobathymetric reconstructions 
have been used to model the diversification of marine organisms (Leprieur et al., 2016). For terrestrial life, one of the key boundary conditions is the availability of robust palaeoelevation models in regularly spaced intervals. While such models have been assembled for proprietary studies in industry-research consortiums, for instance to reconstruct elevation-dependant temperatures (Lunt et al., 2016) and thus constrain vegetation models (Sepulchre et al., 2006), they are currently not freely available for academic research. Furthermore, reconstructions of palaeotopography are inherently biased by the fact that sedimentary basins record the subsidence of the Earth's crust in relatively great detail, while erosion destroys significant information on the temporal dynamics in the extent and height of mountain ranges. The availability of global and regional crustal-scale data sets (e.g. Pasyanos et al., 2014), along with improved computational tools, creates potential avenues to construct palaeoelevation models. These can be further augmented with more detailed regional estimates of palaeoelevation in existing databases including thermochronology (e.g. Barnes et al., 2012) and isotopes studies (e.g. Campani et al., 2012). Effort should be invested in such open access reconstruction to produce a benchmark data set to model terrestrial biodiversity dynamics.

\section{CONCLUSIONS}

The goal of the present analysis is to encourage research that bridges palaeobiology with macroecology using palaeogeographies. Accounting for deep time geomorphological events in spatial models of extant biodiversity is not straightforward, and even if our study proposes a first illustrative approach, it should motivate further development. A new generation of biodiversity models could explicitly model species diversification from the spatio-temporal sequence of environmental conditions (Gotelli et al., 2009). Based on reconstructed palaeohabitats, spatial diversification models may track the distribution of lineages in grid cells, as well as their genealogy, which can be compared with multiple sources of empirical evidence, including biodiversity metrics. Leprieur et al. (2016) showed the interest of such an approach to understand tropical marine diversification, which can be compared to current patterns and the fossil records. To this aim, more effort should be invested in producing openly accessible palaeoenvironmental maps that can be coupled with mechanistic models to understand the spatial dynamics of species diversification. As stated by Myers \& Giller (1988), 'To progress, biogeography must attempt to integrate divergent interests and determine how speciation, adaptation and ecological processes interact with one another and with geology and climate to produce distributional patterns of the world's biota'. We now have the tools to realize this research agenda and quantify the role of historical habitat dynamics within a fully spatial framework. Acknowledging the limitations of the present model, we stress the need for further research into the influence of past habitat dynamics associated with plate tectonics on the spatial distribution of current biodiversity.

\section{ACKNOWLEDGEMENTS}

We thank Cédric Gaucherel and the anonymous reviewers who provided suggestions to improve the manuscript. We also thank Kew Botanical Garden for providing the global checklists of plant species. This study was financed by the Swiss National Fund SNSF project REEFISH no. 310030E-164294.

\section{REFERENCES}

Ali JR, Aitchison JC. 2014. Exploring the combined role of eustasy and oceanic island thermal subsidence in shaping biodiversity on the Galapagos. Journal of Biogeography 41: 1227-1241.

Ali JR, Huber M. 2010. Mammalian biodiversity on Madagascar controlled by ocean currents. Nature 463: 653-656.

Bacon CD, Michonneau F, Henderson AJ, McKenna MJ, Milroy AM, Simmons MP. 2013. Geographic and taxonomic disparities in species diversity: dispersal and diversification rates across Wallace's line. Evolution 67: 2058-2071.

Badgley C. 2010. Tectonics, topography, and mammalian diversity. Ecography 33: 220-231.

Bagley JC, Johnson JB. 2014. Phylogeography and biogeography of the lower Central American Neotropics: diversification between two continents and between two seas. Biological Reviews of the Cambridge Philosophical Society 89: 767-790.

Barker FK, Cibois A, Schikler P, Feinstein J, Cracraft J. 2004. Phylogeny and diversification of the largest avian radiation. Proceedings of the National Academy of Sciences of the United States of America 101: 11040-11045.

Barluenga M, Stölting KN, Salzburger W, Muschick M, Meyer A. 2006. Sympatric speciation in Nicaraguan crater lake cichlid fish. Nature 439: 719-723.

Barnes JB, Ehlers TA, Insel N, et al. 2012. Linking orography, climate, and exhumation across the central Andes. Geology 40: 1135-1138.

Bellwood DR, Hughes TP, Connolly SR, Tanner J. 2005. Environmental and geometric constraints on Indo-Pacific coral reef biodiversity. Ecology Letters 8: 643-651.

Bidegaray-Batista L, Arnedo MA. 2011. Gone with the plate: the opening of the Western Mediterranean basin drove the diversification of ground-dweller spiders. $B M C$ Evolutionary Biology 11: 317. 
BirdLife International \& NatureServe. 2015. Bird species distribution maps of the world. Cambridge, UK/Arlington, USA: BirdLife International/NatureServe.

Bowman J, Jaeger JA, Fahrig L. 2002. Dispersal distance of mammals is proportional to home range size. Ecology 83: 2049-2055.

Briand F, Cohen JE. 1987. Environmental correlates of food chain length. Science 238: 956-960.

Briggs JC. 1987. Biogeography and plate tectonics, Vol. 10. Amsterdam: Elsevier.

Briggs JC. 2003. The biogeographic and tectonic history of India. Journal of Biogeography 30: 381-388.

Campani M, Mulch A, Kempf O, Schluneggere F, Mancktelowf N. 2012. Miocene paleotopography of the Central Alps. Earth and Planetary Science Letters 337: 174-185.

Condamine FL, Sperling FA, Wahlberg N, Rasplus JY, Kergoat GJ. 2012. What causes latitudinal gradients in species diversity? Evolutionary processes and ecological constraints on swallowtail biodiversity. Ecology Letters 15: 267-277.

Contreras-Medina R, Morrone JJ, Lunz Vega I. 2001. Biogeographic methods identify gymnosperm biodiversity hotspots. Die Naturwissenschaften 88: 427-430.

Couvreur TLP. 2015. Odd man out: why are there fewer plant species in African rain forests? Plant Systematics and Evolution 301: 1299-1313.

Cowie RH, Holland BS. 2006. Dispersal is fundamental to biogeography and the evolution of biodiversity on oceanic islands. Journal of Biogeography 33: 193-198.

Craw D, Upton P, Burridge CP, Burridge CP, Wallis GP, Waters JM. 2016. Rapid biological speciation driven by tectonic evolution in New Zealand. Nature Geoscience 9: 140

Currie DJ. 1991. Energy and large-scale patterns of animaland plant-species richness. The American Naturalist 137: $27-49$.

Davies RG, Orme CDL, Storch D, Olson VA, Thomas GH, Ross SG, Ding T, Rasmussen PC, Bennett PM, Owens IPF, Blackburn TM, Gaston KJ. 2007. Topography, energy and the global distribution of bird species richness. Proceedings of the Royal Society of London B: Biological Sciences 274: 1189-1197.

Descombes P, Leprieur F, Albouy C, Heine C, Pellissier L. 2017. Spatial imprints of plate tectonics on extant richness of terrestrial vertebrates. Journal of Biogeography 44: 1185-1197.

Dynesius M, Jansson R, Fischer AG. 2000. Evolutionary consequences of changes in species' geographical distributions driven by Milankovitch climate oscillations. Proceedings of the National Academy of Sciences of the United States of America 97: 9115-9120.

Futuyma DJ, Mayer GC. 1980. Non-allopatric speciation in animals. Systematic Zoology 29: 254

Gastauer M, Saporetti-Junior AW, Magnago LFS, Cavender-Bares J, Meira-Neto JAA. 2015. The hypothesis of sympatric speciation as the dominant generator of endemism in a global hotspot of biodiversity. Ecology and Evolution 5: 5272-5283.
Gillespie RG, Roderick GK. 2014. Evolution: geology and climate drive diversification. Nature 509: 297-298.

Gotelli NJ, Anderson MJ, Arita HT, Chao A, Colwell RK, Connolly SR, Currie DJ, Dunn RR, Graves GR, Green JL, Grytnes JA, Jiang YH, Jetz W, Kathleen Lyons S, McCain CM, Magurran AE, Rahbek C, Rangel TF, Soberón J, Webb CO, Willig MR. 2009. Patterns and causes of species richness: a general simulation model for macroecology. Ecology Letters 12: 873-886.

Graham CH, Moritz C, Williams SE. 2006. Habitat history improves prediction of biodiversity in rainforest fauna. Proceedings of the National Academy of Sciences of the United States of America 103: 632-636.

Guzmán B, Vargas P. 2009. Long-distance colonization of the Western Mediterranean by Cistus ladanifer (Cistaceae) despite the absence of special dispersal mechanisms. Journal of Biogeography 36: 954-968.

Harbaugh DT, Wagner WL, Allan GJ, Zimmer EA. 2009. The Hawaiian Archipelago is a stepping stone for dispersal in the Pacific: an example from the plant genus Melicope (Rutaceae). Journal of Biogeography 36: 230-241.

Hawkins BA, Field R, Cornell HV, Currie DJ, Guégan JF, Kaufman DM, Kerr JT, Mittelbach GG, Oberdorff T, O'Brien EM, Porter EE, Turner JRG. 2003. Energy, water and broad-scale geographic patterns of species richness. Ecology 84: 3105-3117.

Heine C, Yeo LG, Müller RD. 2015. Evaluating global paleoshoreline models for the Cretaceous and Cenozoic. Australian Journal of Earth Sciences 62: 1-13.

Hodge JR, Bellwood DR. 2016. The geography of speciation in coral reef fishes: the relative importance of biogeographical barriers in separating sister-species. Journal of Biogeography 43: 1324-1335.

Hoorn C, Wesselingh FP, ter Steege H, Bermudez MA, Mora A, Sevink J, Sanmartín I, Sanchez-Meseguer A, Anderson CL, Figueiredo JP, Jaramillo C, Riff D, Negri FR, Hooghiemstra H, Lundberg J, Stadler T, Särkinen T, Antonelli A. 2010. Amazonia through time: Andean uplift, climate change, landscape evolution, and biodiversity. Science 330: 927-931.

Hurlbert AH, Jetz W. 2007. Species richness, hotspots, and the scale dependence of range maps in ecology and conservation. Proceedings of the National Academy of Sciences of the United States of America 104: 13384-13389.

Imhoff ML, Bounoua L. 2006. Exploring global patterns of net primary production carbon supply and demand using satellite observations and statistical data. Journal of Geophysical Research: Atmospheres 111: D22S12.

Jetz W, Thomas GH, Joy JB, Hartmann K, Mooers AO. 2012. The global diversity of birds in space and time. Nature 491: 444-448.

Kay RF, Madden RH, Van Schaik C, Higdon D. 1997. Primate species richness is determined by plant productivity: implications for conservation. Proceedings of the National Academy of Sciences of the United States of America 94: 13023-13027.

Keith SA, Baird AH, Hughes TP, Madin JS, Connolly SR. 2013. Faunal breaks and species composition of Indo-Pacific corals: the role of plate tectonics, environment and habitat 
distribution. Proceedings of the Royal Society of London B: Biological Sciences 280: 20130818.

Kerkhoff AJ, Moriarty PE, Weiser MD. 2014. The latitudinal species richness gradient in New World woody angiosperms is consistent with the tropical conservatism hypothesis. Proceedings of the National Academy of Sciences of the United States of America 111: 8125-8130.

Kier G, Kreft H, Lee TM, Jetz W, Ibisch PL, Nowickic C, Mutkea J, Barthlotta W. 2009. A global assessment of endemism and species richness across island and mainland regions. Proceedings of the National Academy of Sciences of the United States of America 106: 9322-9327.

Kissling WD, Carl G. 2008. Spatial autocorrelation and the selection of simultaneous autoregressive models. Global Ecology and Biogeography 17: 59-71.

Kreft H, Jetz W. 2007. Global patterns and determinants of vascular plant diversity. Proceedings of the National Academy of Sciences of the United States of America 104: 5925-5930.

Lavergne S, Hampe A, Arroyo J. 2013. In and out of Africa: how did the Strait of Gibraltar affect plant species migration and local diversification? Journal of Biogeography 40: 24-36.

Leprieur F, Descombes P, Gaboriau T, Cowman PF, Parravicini V, Kulbicki M, Melián CJ, de Santana CN, Heine C, Mouillot D, Bellwood DR, Pellissier L. 2016. Plate tectonics drive tropical reef biodiversity dynamics. Nature Communications 7: 11461.

Lester SE, Ruttenberg BI, Gaines SD, Kinlan BP. 2007. The relationship between dispersal ability and geographic range size. Ecology Letters 10: 745-758.

Li JT, Li Y, Klaus S, Rao DQ, Hillis DM, Zhang YP. 2013. Diversification of rhacophorid frogs provides evidence for accelerated faunal exchange between India and Eurasia during the Oligocene. Proceedings of the National Academy of Sciences of the United States of America 110: 3441-3446.

Luiz OJ, Allen AP, Robertson DR, Floeter SR, Kulbicki M, Vigliola L, Becheler R, Madina JS. 2013. Adult and larval traits as determinants of geographic range size among tropical reef fishes. Proceedings of the National Academy of Sciences of the United States of America 110: 16498-16502.

Luna-Vega I, Contreras-Medina R. 2010. Plant biodiversity hotspots and biogeographic methods. In: Rescigno V, Maletta S, eds. Biodiversity hotspots. New York: Nova Science Publishers, 181-191.

Lunt DJ, Farnsworth A, Loptson C, Foster GL, Markwick P, O'Brien CL, Pancost RD, Robinson SA, Wrobel N. 2016. Palaeogeographic controls on climate and proxy interpretation. Climate of the Past 12: 1181-1198.

Magallón S, Castillo A. 2009. Angiosperm diversification through time. American Journal of Botany 96: 349-365.

Magri D, Fineschi S, Bellarosa R, Buonamici A, Sebastiani F, Schirone B, Simeone MC, Vendramin GG. 2007. The distribution of Quercus suber chloroplast haplotypes matches the palaeogeographical history of the western Mediterranean. Molecular Ecology 16: 5259-5266.

Marin J, Hedges SB. 2016. Time best explains global variation in species richness of amphibians, birds and mammals. Journal of Biogeography 43: 1069-1079.
Meredith RW, Janečka JE, Gatesy J, Ryder OA, Fisher CA, Teeling EC, Goodbla A, Eizirik E, Simão TL, Stadler T, Rabosky DL, Honeycutt RL, Flynn JJ, Ingram CM, Steiner C, Williams TL, Robinson TJ, Burk-Herrick A, Westerman M, Ayoub NA, Springer MS, Murphy WJ. 2011. Impacts of the Cretaceous Terrestrial Revolution and $\mathrm{KPg}$ extinction on mammal diversification. Science 334: 521-524.

Mittelbach GG, Schemske DW, Cornell HV, Allen AP, Brown JM, Bush MB, Harrison SP, Hurlbert AH, Knowlton N, Lessios HA, McCain CM, McCune AR, McDade LA, McPeek MA, Near TJ, Price TD, Ricklefs RE, Roy K, Sax DF, Schluter D, Sobel JM, Turelli M. 2007. Evolution and the latitudinal diversity gradient: speciation, extinction and biogeography. Ecology Letters 10: 315-331.

Molina-Venegas R, Aparicio A, Lavergne S, Arroyo J. 2015. The building of a biodiversity hotspot across a landbridge in the Mediterranean. Proceedings of the Royal Society of London B: Biological Sciences 282: 20151116.

Morley RJ. 1998. Palynological evidence for tertiary plant dispersals in the SE Asian region in relation to plate tectonics and climate. In: Hall R, Holloway JD, eds. Biogeography and Geological Evolution of SE Asia. Leiden: Backhuys, 211-234.

Mouillot D, Albouy C, Guilhaumon F, Ben Rais Lasram F, Coll M, Devictor V, Meynard CN, Pauly D, Tomasini JA, Troussellier M, Velez L, Watson R, Douzery EJ, Mouquet N. 2011. Protected and threatened components of fish biodiversity in the Mediterranean Sea. Current Biology 21: 1044-1050.

Müller RD, Sdrolias M, Gaina C, Steinberger B, Heine C. 2008. Long-term sea-level fluctuations driven by ocean basin dynamics. Science 319: 1357-1362.

Müller RD, Seton M, Zahirovic S, Williams SE, Matthews KJ, Wright NM, Shephard GE, Maloney KT, BarnettMoore N, Hosseinpour M, Bower DJ, Cannon J. 2016. Ocean basin evolution and global-scale plate reorganization events since Pangea breakup. Annual Review of Earth and Planetary Sciences 44: 107-138.

Myers AA, Giller PS. 1988. Process, pattern and scale in biogeography. In: Myers AA, Giller PS, eds. Analytical biogeography. Dordrecht: Springer Netherlands, 3-12.

Near TJ, Dornburg A, Kuhn KL, Eastman JT, Pennington JN, Patarnelloe T, Zanef L, Fernándezg DA, Jonesh CD. 2012. Ancient climate change, antifreeze, and the evolutionary diversification of Antarctic fishes. Proceedings of the National Academy of Sciences of the United States of America 109: 3434-3439.

Palumbi SR. 1994. Genetic divergence, reproductive isolation, and marine speciation. Annual Review of Ecology and Systematics 25: 547-572.

Pasyanos ME, Masters TG, Laske G, Zhitu M. 2014. LITHO1.0: an updated crust and lithospheric model of the Earth. Journal of Geophysical Research: Solid Earth 119: 2153-2173.

Pellissier L, Leprieur F, Parravicini V, Cowman PF, Kulbicki M, Litsios G, Olsen SM, Wisz MS, Bellwood DR, Mouillot D. 2014. Quaternary coral reef refugia preserved fish diversity. Science 344: 1016-1019. 
Peter HR, Axelrod DI. 1975. History of the flora and fauna of Latin America: the theory of plate tectonics provides a basis for reinterpreting the origins and distribution of the biota. American Scientist 63: 420-429.

Pulido-Santacruz P, Weir JT. 2016. Extinction as a driver of avian latitudinal diversity gradients. Evolution 70: 860-872.

Pyron RA. 2014. Temperate extinction in squamate reptiles and the roots of latitudinal diversity gradients. Global Ecology and Biogeography 23: 1126-1134.

Qian H, Wang X, Wang S, Li Y. 2007. Environmental determinants of amphibian and reptile species richness in China. Ecography 30: 471-482.

Rahbek C, Gotelli NJ, Colwell RK, Entsminger GL, Rangel TFLVB, Graves GR. 2007. Predicting continental-scale patterns of bird species richness with spatially explicit models. Proceedings of the Royal Society of London B: Biological Sciences 274: 165-174.

Raven PH, Axelrod DI. 1974. Angiosperm biogeography and past continental movements. Annals of the Missouri Botanical Garden 61: 539-673.

Renema W, Bellwood DR, Braga JC, Bromfield K, Hall R, Johnson KG, Lunt P, Meyer CP, McMonagle LB, Morley RJ, O'Dea A, Todd JA, Wesselingh FP, Wilson ME, Pandolfi JM. 2008. Hopping hotspots: global shifts in marine biodiversity. Science 321: 654-657.

Richardson JE, Bakar AM, Tosh J, Armstrong K, Smedmark J, Anderberg AA, Slik F, Wilkie P. 2014. The influence of tectonics, sea-level changes and dispersal on migration and diversification of Isonandreae (Sapotaceae). Botanical Journal of the Linnean Society 174: 130-140.

Ricklefs R. 2004. A comprehensive framework for global patterns in biodiversity. Ecology Letters 7: 1-15.

Ricklefs RE, He F. 2016. Region effects influence local tree species diversity. Proceedings of the National Academy of Sciences of the United States of America 113: 674-679.

Ricklefs RE, Latham RE. 1993. Global patterns of diversity in mangrove floras. Chicago: University of Chicago Press.

Rosauer DF, Jetz W. 2015. Phylogenetic endemism in terrestrial mammals. Global Ecology and Biogeography 24: 168-179.

Rosauer DF, Laffan SW, Crisp MD, Donnellan SC, Cook LG. 2009. Phylogenetic endemism: a new approach for identifying geographical concentrations of evolutionary history. Molecular Ecology 18: 4061-4072.

Sandel B, Arge L, Dalsgaard B, Davies RG, Gaston KJ, Sutherland WJ, Svenning JC. 2011. The influence of late quaternary climate-change velocity on species endemism. Science 334: 660-664.
Santos JC, Coloma LA, Summers K, Caldwell JP, Ree R, Cannatella DC. 2009. Amazonian amphibian diversity is primarily derived from late Miocene Andean lineages. PLoS Biology 7: e1000056.

Sbrocco EJ, Barber PH. 2013. MARSPEC: ocean climate layers for marine spatial ecology. Ecology 94: 979.

Sepulchre P, Ramstein G, Fluteau F, Schuster M, Tiercelin JJ, Brunet M. 2006. Tectonic uplift and Eastern Africa aridification. Science 313: 1419-1423.

Sommer B, Harrison PL, Beger M, Pandolfi JM. 2014. Trait-mediated environmental filtering drives assembly at biogeographic transition zones. Ecology 95: 1000-1009.

Steeman ME, Hebsgaard MB, Fordyce RE, Ho SY, Rabosky DL, Nielsen R, Rahbek C, Glenner H, Sørensen MV, Willerslev E. 2009. Radiation of extant cetaceans driven by restructuring of the oceans. Systematic Biology 58: 573-585.

Stein A, Gerstner K, Kreft H. 2014. Environmental heterogeneity as a universal driver of species richness across taxa, biomes and spatial scales. Ecology Letters 17: 866-880.

Svenning JC, Eiserhardt WL, Normand S, Ordonez A, Sandel B. 2015. The influence of paleoclimate on presentday patterns in biodiversity and ecosystems. Annual Review of Ecology Evolution and Systematics 46: 551-572.

Toussaint EFA, Hall R, Monaghan MT, Sagata K, Ibalim S, Shaverdo HV, Vogler AP, Pons J, Balke M. 2014. The towering orogeny of New Guinea as a trigger for arthropod megadiversity. Nature Communications 5: 785-792.

Vetaas OR, Grytnes JA. 2002. Distribution of vascular plant species richness and endemic richness along the Himalayan elevation gradient in Nepal. Global Ecology and Biogeography 11: 291-301.

Waide RB, Willig MR, Steiner CF, Mittelbach G, Gough L, Dodson SI, Juday GP, Parmenter R. 1999. The relationship between productivity and species richness. Annual Review of Ecology and Systematics 30: 257-300.

Warren BH, Strasberg D, Bruggemann JH, et al. 2010. Why does the biota of the Madagascar region have such a strong Asiatic flavour? Cladistics 26: 526-538.

Wilf P, Johnson KR, Cúneo NR, Smith ME, Singer BS, Gandolfo MA. 2005. Eocene plant diversity at Laguna del Hunco and Río Pichileufú, Patagonia, Argentina. The American Naturalist 165: 634-650.

Xiang Q (Jenny), Soltis DE. 2001. Dispersal-vicariance analyses of intercontinental disjuncts: historical biogeographical implications for angiosperms in the Northern Hemisphere. International Journal of Plant Sciences 162: S29-S39.

\section{SUPPORTING INFORMATION}

Additional Supporting Information may be found in the online version of this article at the publisher's web-site:

Figure S1. Maps of the terrestrial areas predicted by the model under an allopatric speciation hypothesis and dispersal across sea straits, for different values of the dispersal distance parameter.

Figure S2. Maps of the terrestrial areas favourable for allopatric speciation predicted by the model for several values of the dispersal distance parameter and incorporating extinction, as a linearly decreasing function from the pole to the equator. 
Figures S3. Maps of the coastal marine areas favourable for allopatric speciation predicted by the model for several values of the dispersal distance parameter.

Figures S4. Maps of the coastal marine areas favourable for allopatric speciation predicted by the model for several values of the dispersal distance parameter and incorporation extinction, as a linearly decreasing function from the pole to the equator.

Figure S5. Map of the potential hotspots for allopatric speciation across sea straits for the terrestrial (A) and freshwater species (B) and across reef separated by deep water for marine species (C).

Figure S6. Map of the potential hotspots for allopatric speciation across sea straits for the terrestrial (A) and freshwater species (B) and across reefs separated by deep water for marine species (C), with extinction incorporated as a decreasing Gaussian function from the pole to the equator.

Figure S7. Map of the terrestrial endemic richness calculated as the sum of the inverse range size of all species occurring in a given cell for terrestrial groups.

Figure S8. Map of the freshwater endemic richness calculated as the sum of the inverse range size of all species occurring in a given cell for freshwater groups.

Figure S9. Map of the marine endemic richness calculated as the sum of the inverse range size of all species occurring in a given cell for marine groups.

Figure S10. Map of endemic richness compared to the map of phylogenetic endemism for mammals. 